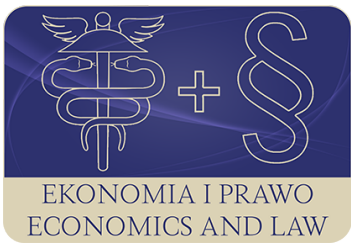

EKONOMIA I PRAWO. ECONOMICS AND LAW

Volume 19, Issue 4, December 2020

p-ISSN 1898-2255, e-ISSN 2392-1625

www.economicsandlaw.pl

ORIGINAL ARTICLE

received 30.03.2019; revised 02.03.2020; accepted 31.12.2020

Citation: Pleśniarska, A. (2020). Knowledge flows in contemporary economies: expectations and the European Union results. Ekonomia i Prawo. Economics and Law, 19(4): 773-787.

doi:10.12775/EiP.2020.050.

\title{
Knowledge flows in contemporary economies: expectations and the European Union results
}

\author{
ALEKSANDRA PLEŚNIARSKA \\ Cracow University Of Economics, Institute of Economics, Department of European Studies \\ and Economic Integration, ul. Rakowicka 27, 31-510 Krakow, Poland \\ ๑aleksandra.plesniarska@uek.krakow.pl \\ (D) orcid.org/0000-0003-3257-8416
}

\begin{abstract}
Motivation: Access to knowledge and the ability to absorb it are increasingly becoming the decisive factor in the level of development and the pace of economic growth. Knowledge transfer is a complex process that can have both an internal dimension (between entities within a given country) and an international one (between domestic and foreign entities). In this context, knowledge flows in the area of science and innovation deserve special attention.

Aim: The main purpose of the article is to present the multidimensional nature of knowledge flows and to identify the position of the EU in comparison with global competitors in this filed, especially considering the global science and innovation context. What are the channels of knowledge flow? To what extent does the EU participate in the international knowledge flows? What are the EU expectations in this area? This article endeavours to answer the questions above.

Results: The article systematizes information on knowledge flows in economy and supplements it with a comparative analysis, which allows for better understanding of the international position of the European Union in this field. The conclusion states that despite

lagging behind the United States, European science is becoming increasingly more open-access oriented and the EU is still among the leaders of international scientific cooperation.
\end{abstract}


Keywords: knowledge transfer; international transfer of knowledge; European Union; open science; international scientific cooperation

JEL: I2; O3

\section{Introduction}

The last several decades have been a period of significant increase in the role of knowledge in production, but also in trade (including international trade). The ongoing development of information and communication technologies (ICT) is conducive to increasing possibilities of access to knowledge and facilitates its transfer. Access to knowledge and the ability to absorb it are increasingly becoming the decisive factor in the level of development and the pace of economic growth. Therefore, the development of a knowledge-based economy is a desirable direction of development for countries. In the global aspect, knowledge flows (in many dimensions) are observed. However, knowledge flows in the area of science and innovation deserve special attention.

The main purpose of the article is to present the multidimensional nature of knowledge flows and to identify the position of the EU in comparison with global competitors in this field, especially considering the global science and innovation context. What are the channels of knowledge flows? To what extent does the EU participate in international knowledge flows? What are the EU expectations in this area? This article endeavours to answer the questions above.

In the theoretical section of the article, selected aspects of knowledge transfer and its channels are presented. The research method adopted here involves a literature survey. Subsequently, in the empirical section, an analysis of selected indicators, which present position of the EU in comparison with global competitors in the aspects of knowledge flows, especially in the area of science, is conducted. The main line of investigation is a comparative analysis which refers to the international statistical databases. This section also offers discussion of challenges and expectations of the EU in this field.

\section{Literature review}

There is a clear difference between knowledge and information. The latter is usually defined as 'messages or data, which can easily be codified and therefore transmitted, received, transferred and stored at low costs', whereas knowledge consists of organised or structured information (Karlsson \& Gråsjö, 2014, p. 416). Lundvall (2004, pp. 21-42) notes that knowledge and information appear in economic models in two different contexts. Firstly, with reference to a fundamental assumption of microeconomics (i.e., an economic system is based on rational choices made by individual agents), having information and ability to process the information are crucial issues. Secondly, knowledge is regarded as an asset. In that context, knowledge may appear both as an input (competence) and output (innovation) in the production process. Lundvall 
(2004, pp. 21-42) points out that knowledge can be also perceived as privately owned and/or bought and sold in the market as a commodity.

Knowledge can either be 'codified' or 'tacit'. Codified knowledge can be expressed through symbolic forms of representation such as written or spoken words. It is mainly contained in documents, databases, and various types of recorded information. It is knowledge that is characterized by the availability and the possibility of use. In contrast, tacit knowledge is challenging to articulate or codify. It is usually a resource of individual skills or experiences. It may also consist of experience and understanding accumulated by an organisation over time. Therefore, tacit knowledge is difficult to transmit (Brant \& Parthasarathy, 2015; Lundvall, 2004, pp. 21-42; see: Polanyi, 1966).

Knowledge is usually neither completely public nor completely private (Lundvall, 2004). Among the categories of knowledge the following should be distinguished: know-what (knowledge about 'facts'), know-how (skills and practical attainments, embodied in persons or embedded in economic agents, such as firms), know-who (involves information about who knows what and who knows what to do, it also involves the social ability to cooperate and communicate with people), and know-why (a capacity to understand and explain, usually refers to science, it is important for technological development) (Karlsson \& Gråsjö, 2014, pp. 413-437; Lundvall, 2004).

Karlsson \& Gråsjö (2014, pp. 417-418) point out three knowledge concepts: scientific knowledge, technological knowledge and entrepreneurial (business) knowledge. From the economic aspect, regardless of the category of knowledge, it is important not only to own knowledge, but also to be able to absorb it and create new knowledge. New knowledge usually arises as a result of sharing/ exchanging knowledge by individuals, e.g. at university or in the research department of an economic agent.

The role of knowledge flow has been emphasised both in theoretical arguments and empirical studies (e.g. Cowan \& Jonard, 2004; Guan \& Chen, 2012). There are many types of knowledge, simple and complex, and they can be diffused through various channels. Morone \& Taylor (2010) point out that among knowledge flows there are phenomena of knowledge gain and knowledge diffusion (scheme 1). Knowledge gain concerns trade exchange between entities. In this aspect, it is necessary to distinguish between knowledge exchange (exchange e.g. knowledge for knowledge) and knowledge trade (e.g. the entity pays for the knowledge received). On the other hand, knowledge diffusion concerns free knowledge flows while agents interact. However, that definition has its weaknesses (it does not describe how knowledge actually flows across agents, nor how it is recombined with the recipient's existing knowledge). For these reasons, Morone \& Taylor (2010, pp. 18-21) suggest decomposition of the knowledge diffusion concept into three subcategories: knowledge spillover, knowledge transfer and knowledge integration. The latter refers to a process which combines dispersed bits of knowledge held by individuals to be applied in a coordinated way, and only on a temporary basis. Conversely, knowledge 
spillover and knowledge transfer denote two similar processes in which bits of knowledge are conveyed from one agent to another. However, knowledge spillover is a kind of process of uncontrolled diffusion of knowledge (e.g. during a conversation with partners), while knowledge transfer is a controlled process, aimed at acquiring specific knowledge. Similarly, Fallah \& Ibrahim (2004, p. 8) note that 'if knowledge is exchanged with the intended people or organisations, it is 'knowledge transfer', any knowledge that is exchanged outside the intended boundary is spillover'.

Knowledge transfer channels can be understood as ways of the transfer of knowledge (Govind \& Küttim, 2016, p. 7). Trippl et al. (2009, pp. 443-462) note four main channels for knowledge transmission, i.e.: market relations, formal networks, spillovers, and informal networks (table 1). It should be noted that all of these are interrelated and often complementary. Trade and formal relationships usually involve monetary or other forms of compensation for particular knowledge flows. The division into exchange of static knowledge (refers to the transfer of 'ready' pieces of information or knowledge from one actor to another) and the exchange of dynamic knowledge (cooperation or other joint activities) are also noteworthy.

Knowledge transfer takes place in trade and non-trade channels. On the one hand, it concerns the trade of high technology goods, the purchase of licenses, patents, and on the other hand, it includes research and development cooperation, publications, exchange of scientists or informal contacts. Knowledge transfer can be considered both in the context of domestic and international flows. It is 'a complex and rapidly evolving phenomenon based on the interactions of several stakeholders' (Giuri et al., 2019, p. 261). In addition, knowledge transfer can take place at various levels of the economy, i.e., at the level of individuals, companies, organisations, but also between economies. Therefore, knowledge transfer refers in a broader sense to the multiple ways in which knowledge from universities and public research institutions can be exploited by firms and researchers to generate economic and social value and industrial development (OECD, 2013, p. 18). Govind \& Küttim (2016, p. 6) stress that international knowledge transfer is a multi-faceted phenomenon whereas 'universities are seen as the main producers of 'new knowledge' which contributes to the development, innovation and competitiveness of companies, regions and countries'.

\section{Methods}

The multidimensional nature of knowledge flows makes them difficult to estimate. In the economic literature, indicators are usually used in the analysis of knowledge flows, mainly referring to patents (e.g. Jinji \& Zhang, 2015; Montobbio et al., 2015) or scientific publications (e.g. Hassan \& Haddawy, 2013). Those indicators enable quantitative measurement. Crespi et al. (2008) point out that in measuring knowledge flows, two main methods are in the lit- 
erature: direct (use information in patent citations) and indirect (combining total factor productivity growth with knowledge). In the EU documents, among the indicators referring to the monitoring of knowledge flows, the following are usually indicated i.a.: open access to scientific publications, public expenditure on $\mathrm{R} \& \mathrm{D}$, international scientific co-publications, share of patents, cooperation between enterprises and universities (European Commission, 2018b). It is noteworthy that usually indicators used in the measurement of knowledge flows are inextricably linked to research and development cooperation.

The methods used in the article include both descriptive and analytical approach, including comparative analysis. The main goal of comparative analysis is to present the position of the EU in comparison with global competitors in the aspects of knowledge flows, especially in the area of science and innovation. Moreover, the main research task is to verify the statement that the European Union is not a world leader in international cooperation in the field of creating patents and publications. For that reason, the subject scope of the analysis covers the European Union (EU-28) as well as the United States, Japan, China and South Korea. Thematic scope of the analysis includes the chosen indicators from the following areas: scientific publications, patents and intellectual property. Those indicators are one of the most commonly used measures in international comparisons (e.g. Report on Science, Research and Innovation Performance of the EU). The analysis allows for a better understanding of the EU's position in the global context. However, there is not enough (available) data for specific years, which made it impossible to make an analysis for a long period. Additional measurement of knowledge flows (data collected in international databases) focuses on codified knowledge, bypassing the aspect of tacit knowledge. It is a significant limitation of the undertaken research.

\section{Results and discussion}

Globalization, increase in importance of ICT and implications of knowledge-driven world cause information and knowledge to become increasingly valuable in the development of economy. In that context, it seems important to ensure that advances in science are open as far as possible. The EU distinguished between two forms of open access: gold open access publishing and green. Within 'gold' open access payment of publication costs is shifted from readers to authors. These costs are usually borne by the university or research institute to which the researcher is affiliated. On the other hand, 'green' open access means self-archiving, the published article is archived by the researcher; however, access to this article is often delayed at the request of the publisher (European Commission, 2012b). As shown in chart 1, scientific publications are becoming increasingly open, both in the EU (from $22.5 \%$ to $35 \%$ ) and internationally in recent years. However, the EU is still lagging behind the United States. The chart 1 also shows differences in the relative share of gold versus 
green open access publications. Relatively highest share of gold open access is in China.

The number of public-private co-publications (chart 2) has fallen in the EU (from 34.7 to 28.7), while in China it more than doubled between 2008 and 2015. The EU was a long way behind the United States, South Korea and Japan in 2015. Moreover, in the US, twice as many publications are created in cooperation with the private sector than in the EU. Additionally, it is worth mentioning that according to the research, there are significant discrepancies in the EU when it comes to the percentage of innovative enterprises which cooperate with universities or research institutes. On average, only one in ten small innovative firms in the EU undertakes cooperation with universities, while every third large enterprise undertakes such cooperation (Pleśniarska, 2018, p. 158).

According to chart 3, the importance of international collaboration rose significantly in all presented countries and in the EU from 2000 to 2016. Although the EU remains the leader, it should be noted that international scientific collaboration has doubled in the US (from 20.6\% to 40.9\%) and Japan (from 17.5\% to $33.4 \%)$. The fact that in this indicator intra-EU publications are also included may have influenced the EU's result positively. Wagner et al. (2015) emphasise that among factors influencing the increase of cooperation between authors the following should be pointed out: improvements in communications technologies, budget pressures on R\&D spending that increase the incentives for collaboration and also the need to coordinate globally such challenges as climate change or access to water and control of infectious diseases.

Data shown in chart 4 is based on the main country affiliation for authors captured in at least two documents published and indexed in the Scopus database over the 2006-2016 period. Counts are based on the number of authors with distinct country affiliations in their first and last recorded publication. The data presents the largest flows taking into account the EU countries as well as the US, China, Japan and Korea. The most international bilateral flows of scientists over the period 2006-2016 involved exchanges with the US. Top connections included only 7 Member States, that is, the United Kingdom, Germany, France, Italy, Spain, the Netherlands, and Ireland. Among the EU Member States, the largest flows were recorded between France and the United Kingdom, as well as France and Germany.

The European Union and the United States lead in international cooperation, proxied by the share of patents with foreign co-inventors in the total number of patents (chart 5). Moreover, the EU's results remained roughly stable from $10.9 \%$ in 2004 to $11.2 \%$ in 2014 in this field. It is noteworthy that in the same period the share of patents with foreign co-inventors increased in the US.

Licensing allows intellectual property developed within firms to be used externally. Firms transfer their intellectual property across national boundaries. The intellectual property includes the use of proprietary right among other patents, trademarks, copyrights, industrial processes and designs. The export revenues for these types of transactions provide a broad indicator of technology 
flows across the global economy. Global exports (receipts for the use of intellectual property) were $\$ 272$ billion in 2016. In spite of the fall in US global share from $54 \%$ (in 2008) to 45\% (in 2016), it was still the world's largest exporter (chart 6). The EU is the second largest global exporter (24\% of global share). Japan's global export (third global exporter) share remained stable between 2008 and 2016.

As a result of the conducted analysis, it should be noted that despite lagging behind the United States, European science is becoming increasingly more open-access oriented and the EU is still among the leaders of international scientific cooperation. However, it is possible to identify implications for the European Union policy (table 2). Referring to the data, it is worth paying attention not only to the EU, but also to its global competitors, especially China, which is getting better and better results (e.g. in scientific publications). The same trend has also been noted in other studies. Schöpfel (2016) notes that the EU Member States produce about one-third of the worldwide scientific articles (however this percentage is slowly eroding) while the share of China and India is increasing. In the future, this may provide a threat to maintaining the EU's position in this field. In addition, Brexit may also affect EU performance. According to the presented data, the largest international bilateral flows of scientific authors occurs between Great Britain and the United States.

It is noteworthy that the EU has been taking actions aimed at supporting knowledge flows for years (especially under soft law). For example, it can point to such documents as:

- Commission Recommendation of 10 April 2008 on the management of intellectual property in knowledge transfer activities and code of practice for universities and other public research organisations (European Commission, 2008);

- Opinion of the European Economic and Social Committee on Cooperation and transfer of knowledge between research organisations, industry and SMEs: an important prerequisite for innovation (own-initiative opinion) (EESC, 2009);

- Commission Recommendation of 17 July 2012 on access to and preservation of scientific information (European Commission, 2012a);

- Communication from the Commission to the European Parliament, the Council, the European Economic and Social Committee and the Committee of the Regions: towards better access to scientific information: boosting the benefits of public investments in research (European Commission, 2012b).

Nowadays one of the most important challenge for the European Union policy makers is creating the European research community. The key expectation, and at the same time the EU's challenge, is to strive for 'openness' which, as a consequence, is to affect further development and establishment of the EU's international position. Openness is important for supporting knowledge flows and building an attractive scientific environment in favour of quality research. One of the last and very important EU initiatives is the concept of three principles: Open Innovation, Open Science and Open to the World, which was launched in 2016. It was implemented to counteract insufficient diffusion 
of technologies and innovations (and thus also knowledge flows) across firms and countries, both between and within sectors (European Commission, 2016). In assumption 'open science' is intended to focus on a new approach to science, whose core should be cooperation and dissemination of science (e.g. access to scientific publications), 'open innovation' focuses on implementing activities supporting robust and strong science-business linkages, and 'open on the world' is intended to eliminate all obstacles in international scientific cooperation. The three mentioned principles set clear directions for development, and thus also the EU's expectations for its future in this area.

The European Union therefore takes a number of actions to support these principles, such as: the European Cloud Initiative, further development of European Research Area, or the programme Horizon 2020. The European Open Science Cloud is underpinned by the European Data Infrastructure initiative. It has the support of about 70 scientific institutions, including the CERN nuclear research centre and the European Molecular Biology Laboratory. This program provides the possibilities to create the shared repository, such as big data storage, quantum technology, and ex-generation supercomputers (Gobble, 2018).

Phillips \& Knoppers (2019, p. 110) note that as open science becomes institutionalized, simultaneously European Union should establish the rules that will shape it, especially concerns data protection and data sharing. It is also important to create an efficient open science information commons to support new discoveries.

At the same time, it should be emphasised that systems supporting research and development are usually the domain of the Member States. Govind \& Küttim (2016, p. 6) stress that most countries have adopted a number of policies and programmes to promote the international transfer of knowledge and technology in order to solve global problems related to the environment, health, security and economic development. It should be noted, therefore, that the international position of the EU is influenced not only by EU decisions or recommendations, but also by the policies pursued by the governments of the Member States.

\section{Conclusion}

Knowledge flows can be seen as an integral part of contemporary developed economies. It is noteworthy that despite lagging behind the United States, European science is becoming increasingly more open-access oriented and the EU is among the leaders of international scientific cooperation. It should be viewed as positive that the EU's initiatives and recommendations supporting to the knowledge flows in economy, are taken. Referring to the results of the comparative analysis, it seems that the European Union should take intensified actions in the area of development of cooperation, not only in the international dimension (e.g., patents with foreign co-inventors), but also in the field of cooperation between science and business (public-private cooperation). A very important 
implication for European policy should be to take two-way and parallel actions in this area. On the one hand, there is still a need to develop knowledge transfer within the EU (between countries, European companies, etc.). On the other hand, the EU should strive to strengthen (or at least maintain) its international position in this area. It should be noted that in order to build European ,openness', the EU has to face several challenges, such as: a need to create a better funding environment which will support Open Science, a need to take action supporting open access, a need for establishing systematic connections between scientific research and international relations, and a need to promote international scientific collaboration (European Commission, 2018a).

Therefore, the knowledge transfer in the economy requires support in many areas, i.e. a financial (support especially in the area of science and innovation through dedicated programmes), a legal (creating regulations that will not only support, but also protect the knowledge flows, e.g. copyright regulations or access to data), a infrastructure (development of platforms and cooperation networks), a scientific environment (promotion of scientific quality and reliability, creating a European scientific community where access to knowledge will be conducive to not only its transfer but its creative use too). Considering the economic dimension of knowledge, support in the area of knowledge flows may also have real results observed in the growth and socio-economic development of European economies.

A further step in this research could be to also present results taking into account other channels of knowledge flows relating to, for example: human resources and their mobility (e.g. human in science and technology, job-to-job mobility), or knowledge flows in the private sector (e.g. high-tech).

\section{References}

Brant, J., \& Parthasarathy, B. (2015). The dynamics of global technology and knowledge flows. ICC Innovation and Intellectual Property Research Paper, 4.

Cowan, R., \& Jonard, N. (2004). Network structure and the diffusion of knowledge. Journal of Economic Dynamics and Control, 28(8). doi:10.1016/j. jedc.2003.04.002.

Crespi, G., Criscuolo, C., Haskel, J., \& Slaughter, M. (2008). Productivity growth, knowledge flows, and spillovers. NBER Working Paper, 13959. doi:10.3386/w13959.

EESC. (2009). Opinion of the European Economic and Social Committee on Cooperation and transfer of knowledge between research organisations, industry and SMEs: an important prerequisite for innovation (own-initiative opinion) (OJ C 218).

European Commission. (2008). Commission Recommendation of 10 April 2008 on the management of intellectual property in knowledge transfer activities and code of practice for universities and other public research organisations (OJ L 146). 
European Commission. (2012a). Commission Recommendation of 17 July 2012 on access to and preservation of scientific information (OJ L 194).

European Commission. (2012b). Communication from the Commission to the European Parliament, the Council, the European Economic and Social Committee and the Committee of the Regions: towards better access to scientific information: boosting the benefits of public investments in research (COM/2012/401).

European Commission. (2016). Open innovation, open science, open to the world: a vision for Europe. Retrieved 14.02.2020 from https: / /ec.europa.eu.

European Commission. (2018a). Europe's future: open innovation, open science, open to the world: reflections of the Research, Innovation and Science Policy Experts (RISE) High Level Group. Retrieved 14.02.2020 from https: / /op.europa. eu.

European Commission. (2018b). Science, research and innovation performance of the EU: strengthening the foundations for Europe's future. Retrieved 14.02.2020 from https://ec.europa.eu.

Fallah, M.H., \& Ibrahim, S. (2004). Knowledge spillover and innovation in technological clusters. In Y.A Hosni, R. Smith, T.M. Khalil (Eds.), IAMOT 2004: 13th international conference on management of technology: new directions in technology management: changing collaboration between government, industry and university. Washington: IAMOT.

Giuri, P., Munari, F., Scandura, A., \& Toschi, L. (2019). The strategic orientation of universities in knowledge transfer activities. Technological Forecasting \& Social Change, 138. doi:10.1016/j.techfore.2018.09.030.

Gobble, M.M. (2018). News and analysis of the global innovation scene. Research-Technology Management, 61(6). doi:10.1080/08956308.2018.151660 8.

Govind, M., \& Küttim, M. (2016). International knowledge transfer from university to industry: a systematic literature review. Research in Economics and Business: Central and Eastern Europe, 8(2).

Guan, J., \& Chen, Z. (2012). Patent collaboration and international knowledge flow. Information Processing and Management, 48(1). doi:10.1016/j. ipm.2011.03.001.

Hassan, S.U., \& Haddawy, P. (2013). Measuring international knowledge flows and scholarly impact of scientific research. Scientometrics, 94(1). doi:10.1007/ sl1192-012-0786-6.

Jinji, N., \& Zhang, X. (2015). International knowledge flows and productivity: intra- vs. inter-industry spillovers. International Economic Journal, 29(3). doi:10.1080/10168737.2015.1041543.

Karlsson, C., \& Gråsjö, U. (2014). Knowledge flows, knowledge externalities, and regional economic development. In M. Fischer, \& P. Nijkamp (Eds.), Handbook of regional science. Berlin: Springer. doi:10.1007/978-3-642-23430-9_25. 
Lundvall, B.A. (2004), The economics of knowledge and learning. In J.L. Christensen \& B.A. Lundvall (Ed.), Product innovation, interactive learning and economic performance. Burlington: Emerald Group.

Montobbio, F., Primi, A., \& Sterzi, V. (2015). IPRS and international knowledge flows: evidence from six large emerging countries. Tijdschrift Voor Economische en Sociale Geografie, 106(2). doi:10.1111/tesg.12131.

Morone, P., \& Taylor, R. (2010). Knowledge diffusion and innovation: modelling complex entrepreneurial behaviors. Cheltenham: Edward Elgar.

National Science Board. (2018). Science \& engineering indicators 2018. Retrieved 27.03.2019 from https://www.nsf.gov.

OECD. (2013). Commercialising public research: new trends and strategies. doi:10.1787/9789264193321-en.

OECD. (2017). International bilateral flows of scientific authors, 2006-16: largest bilateral flows, by first and last recorded main affiliation. doi:10.1787/ sti_scoreboard-2017-graphl08-en.

OECD. (2019). OECD.Stat. Retrieved 26.03.2019 from https://stats.oecd.org.

Phillips, M., \& Knoppers, B.M. (2019). Whose Commons: data protection as a legal limit of open science. The Journal of Law, Medicine \& Ethics, 47(1). doi:10.1177/1073110519840489.

Pleśniarska, A. (2018). The intensity of university-business collaboration in the EU. Acta Universitatis Lodziensis: Folia Oeconomica, 6(339). doi:10.18778/0208-6018.339.09.

Polanyi, M. (1966). The logic of tacit inference. Philosophy, 41(155). doi:10.1017/ s0031819100066110.

Schöpfel, J. (2016). Open supply: on the future of document supply in the world of open science. Interlending \& Document Supply, 44(4). doi:10.1108/ilds-07-2016-0025.

Trippl, M., Tödtling, F., \& Lengauer, L. (2009). Knowledge sourcing beyond buzz and pipelines: evidence from the Vienna software sector. Economic Geography, 85(4). doi:10.1111/j.1944-8287.2009.01047.x.

Wagner, C.S., Park, H.W., \& Leydesdorff, L. (2015). The continuing growth of global cooperation networks in research: a conundrum for national governments. PLoS ONE, 10(7). doi:10.1371/journal.pone.013181.

\section{Acknowledgements}

Author contributions: author has given an approval to the final version of the article.

Funding: this research was funded by the Cracow University of Economics sources.

Note: the results of this study were presented at 10th International Conference on Applied Economics Contemporary Issues in Economy (June 27-28, 2019, Torun, Poland). 


\section{Appendix}

Table 1.

\section{Channels for knowledge transmission}

\begin{tabular}{|c|c|c|}
\hline Specification & Formal/traded relation & Informal/untraded relation \\
\hline \multirow{4}{*}{ static } & market relations & spillovers \\
\hline & - consulting & - recruiting specialists \\
\hline & - licenses & - participating in fairs, conferences \\
\hline & - buying intermediate goods & - reading scientific literature, patent specifications \\
\hline \multirow[b]{2}{*}{ dynamic } & formal networks & informal networks \\
\hline & $\begin{array}{l}\text { - R\&D collaborations } \\
\text { - shared used of R\&D facilities }\end{array}$ & - informal contacts \\
\hline
\end{tabular}

Source: Own preparation based on Trippl et al. (2009, p. 448).

Table 2.

\section{Implications for the European Union policy}

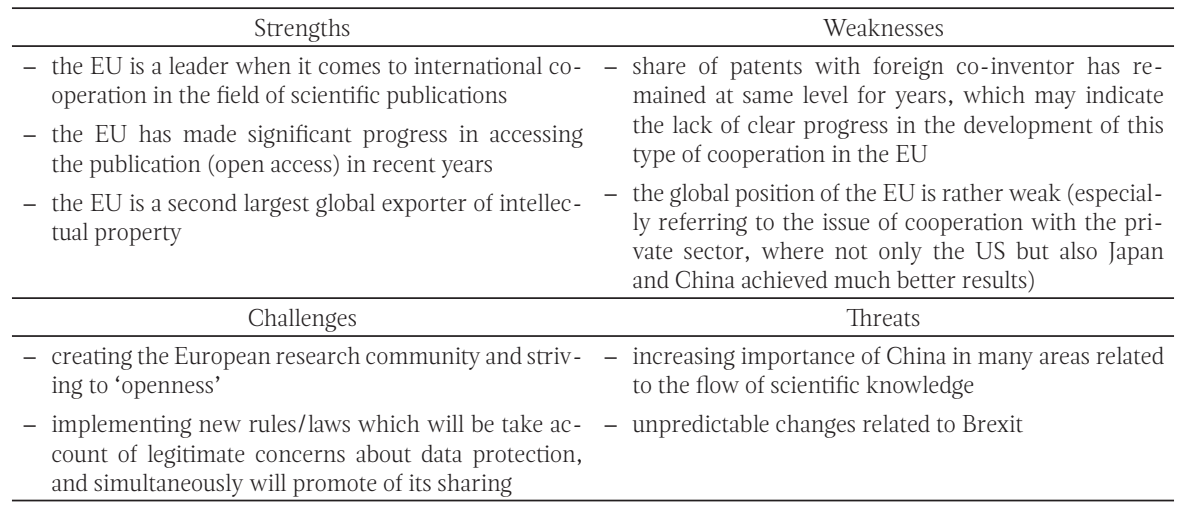

Source: Own preparation.

Scheme 1 .

Taxonomy of knowledge flows by Morone \& Taylor

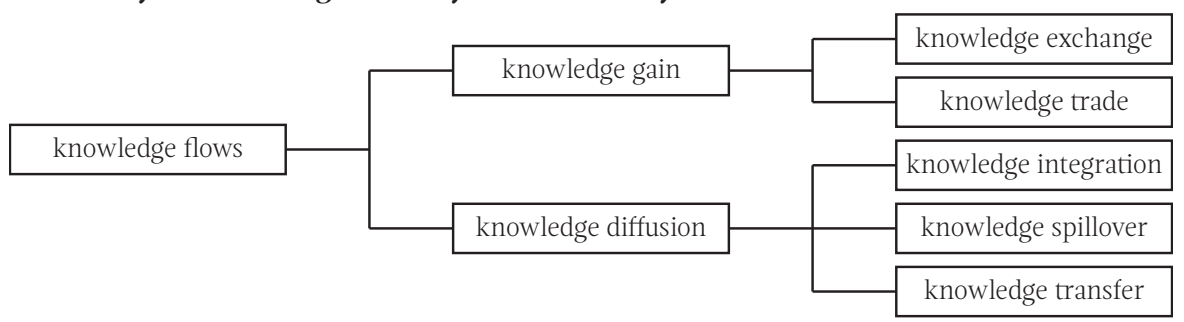

Source: Own preparation based on Morone \& Taylor (2010, pp. 18-21). 


\section{Chart 1.}

Open access scientific publications with digital object identifier (DOI) as \% of total scientific publications with DOI in 2009 and 2016

40

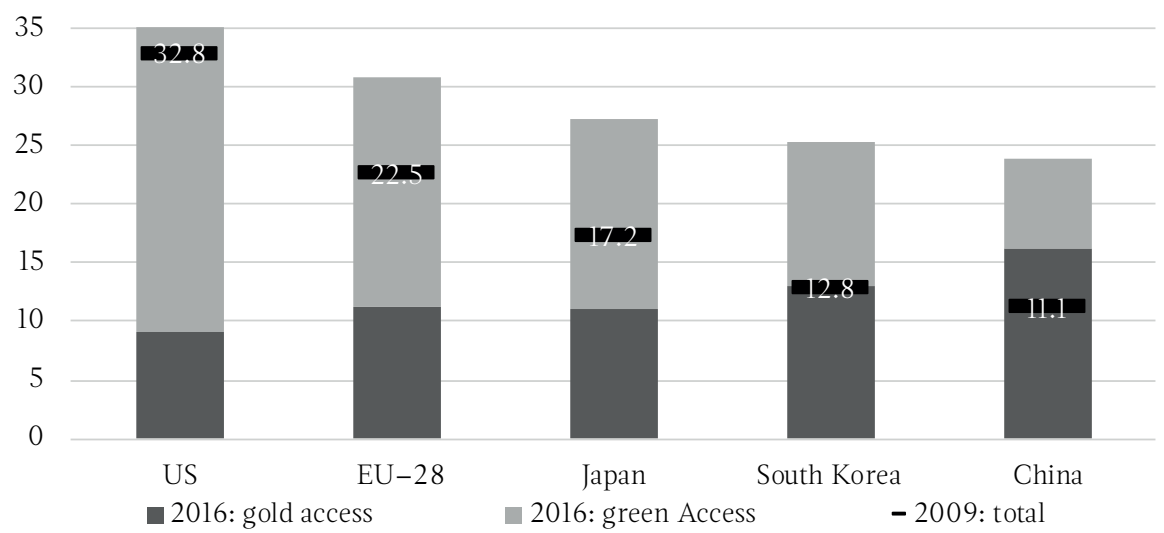

Source: Own preparation based on European Commission (2018b, p. 174).

Chart 2.

Public-private co-authored scientific publications per million populations in 2008 and 2015

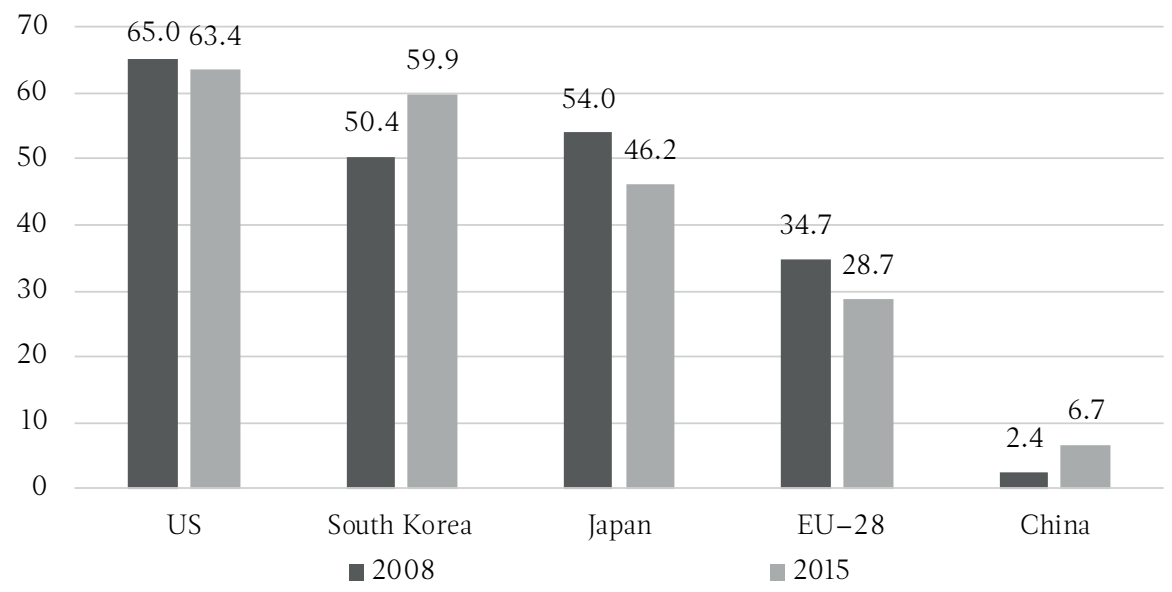

Source: Own preparation based on European Commission (2018b, p. 180). 


\section{Chart 3.}

International scientific co-publications as \% of total scientific publications in 2000 and 2016

60

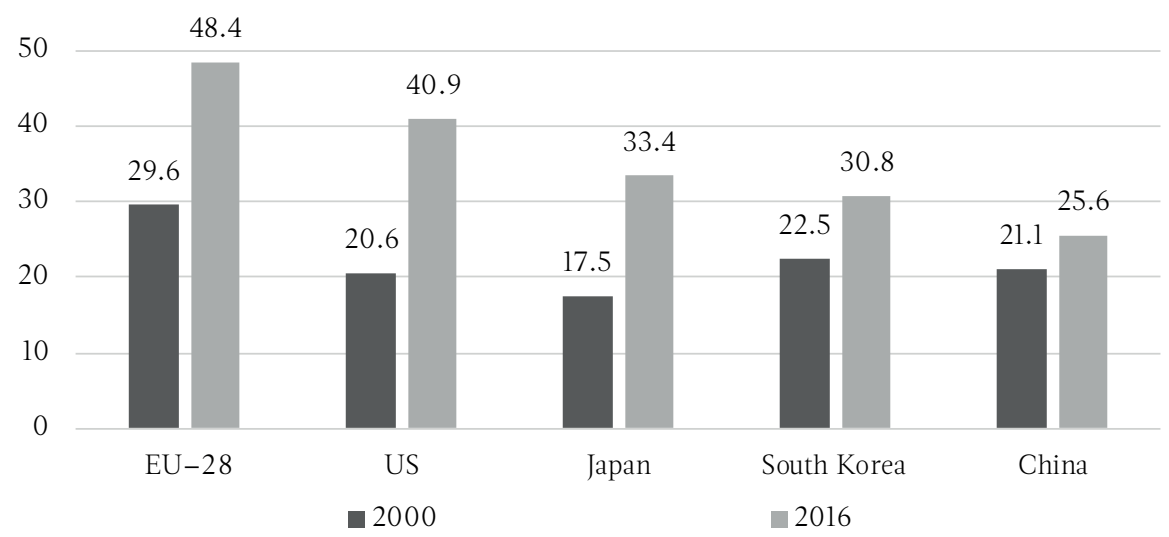

Source: Own preparation based on European Commission (2018b, p. 183).

\section{Chart 4.}

International bilateral flows of scientific authors in 2006-2016

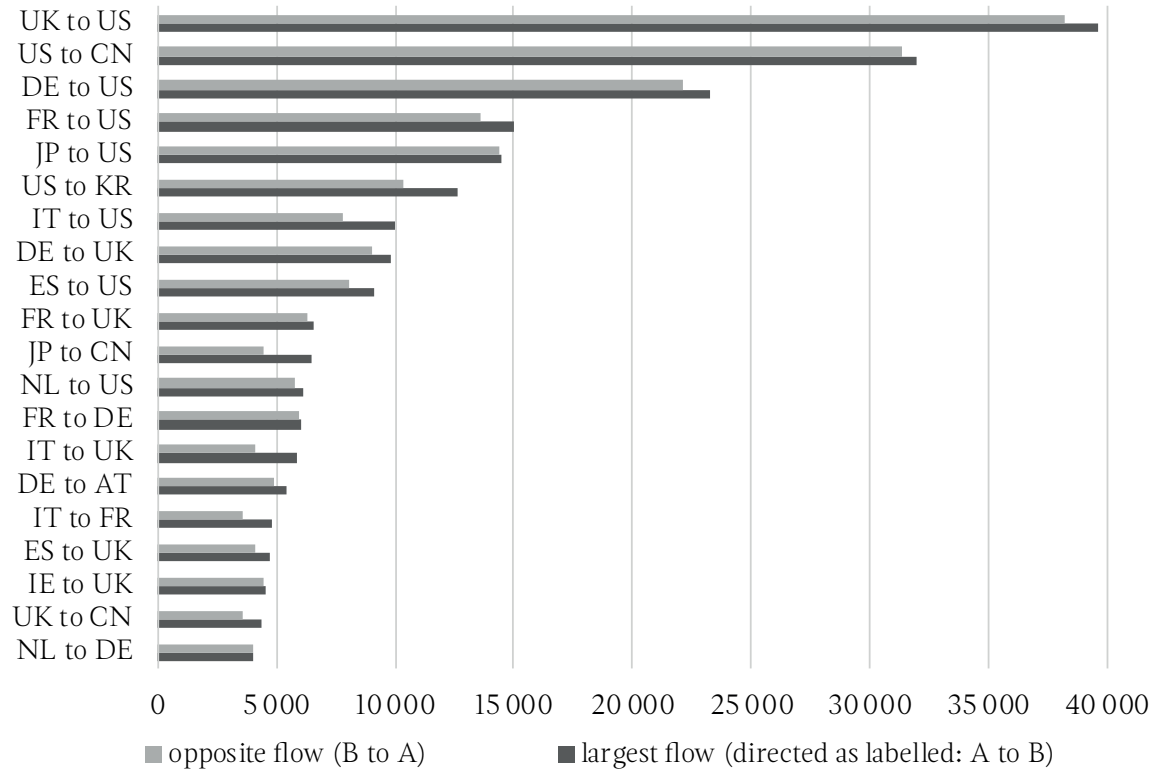

Source: Own preparation based on OECD (2017). 


\section{Chart 5.}

Share of PCT patents with foreign co-inventor(s) in total number of patents in 2004 and 2014 (in \%)

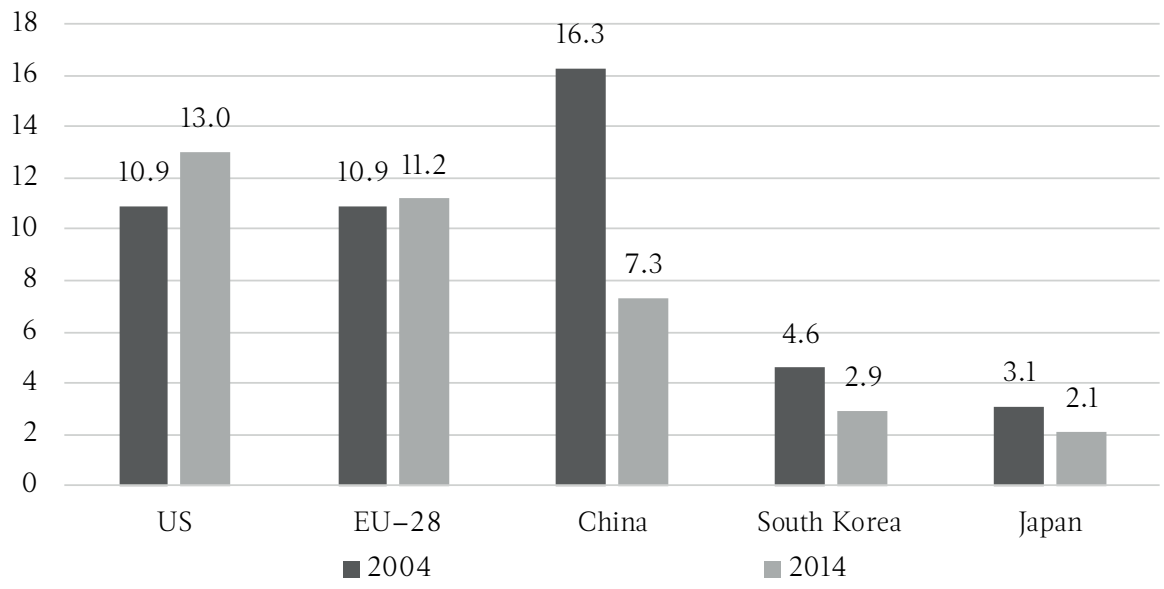

Notes:

Patents filed under the Patent Co-operation Treaty (PCT), at international phase, that designate the European Patent Office.

Source: Own preparation based on OECD (2019).

\section{Chart 6.}

Exports of intellectual property in 2008-2016 (in billions of dollars)

140

120

100
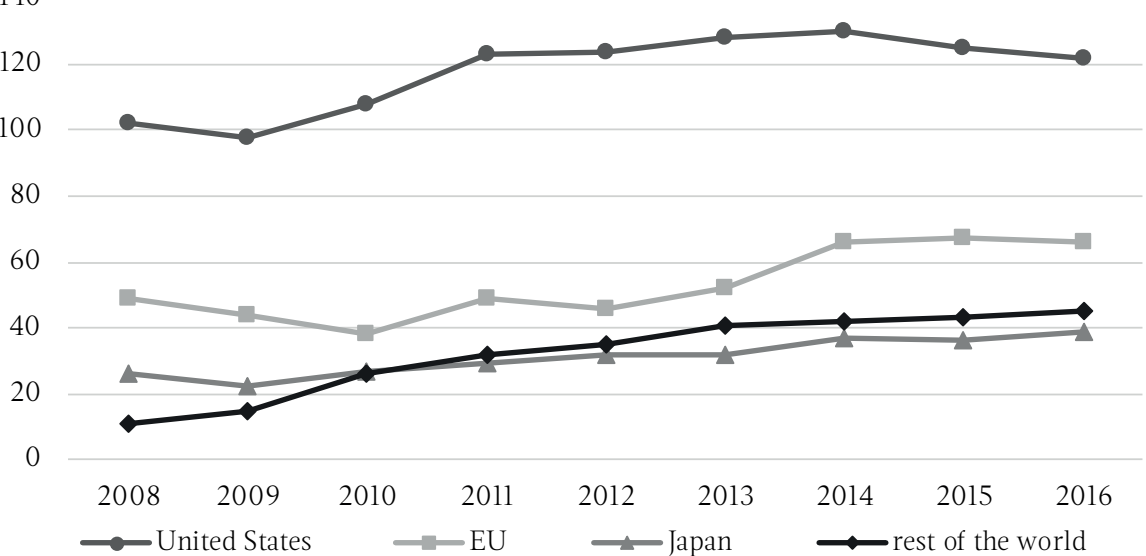

Source: Own preparation based on National Science Board (2018). 
